\title{
Generoll Entomology \\ Spatial and temporal distribution of Helicoverpa zea (Boddie) (Lepidoptera: Noctuidae) and Euxesta spp. (Diptera: Otitidae) in the corn crop
}

\author{
Jessica Vasconcelos Ferreira ${ }^{1} \odot$, Ivan Carlos Fernandes Martins ${ }^{1 \bowtie} \bullet$, Raiana Rocha Pereira ${ }^{2}{ }^{\oplus}$, \\ Rayane Rocha Pereira ${ }^{1 \oplus}$, Mateus Higo Daves Alves ${ }^{1} \oplus$, Lourival Dias Campos $^{1} \oplus$, \\ Marcello Neiva de Mello1® \& Francisco José Sosa Duque ${ }^{3 \oplus}$
}

1. Universidade Federal Rural da Amazônia, Campus Capanema - PA, Brazil. 2. Universidade Federal Rural da Amazônia, Campus Belém - PA., Brazil. 3. Universidade Federal Rural da Amazônia, Campus Capitão Poço - PA, Brazil.

\section{EntomoBrasilis 14: e919 (2021)}

Edited by:

William Costa Rodrigues

\section{Article History:}

Received: $10 . v i i .2020$

Accepted: 25.xi.2020

Published: 13.i.2021

\section{Corresponding author:} Ivan Carlos Fernandes Martins ७icfmartins@yahoo.com.br Funding agencies:

$\begin{array}{llr}\text { * Conselho Nacional de } & \text { de } \\ \text { Desenvolvimento } & \text { Científico } & e \\ \text { Tecnológico }(C N P q) & & \end{array}$

\begin{abstract}
The aim of this study was to verify the pattern and the spatial and temporal behavior of the corn earworm and corn-silk fly in the corn crop. Hybrid corn was planted without chemical insect control in one hectare, this area was divided into 100 plots of $100 \mathrm{~m}^{2}$. For the occurrence of Euxesta spp. all parts of the plants were visually analyzed, whereas for Helicoverpa zea (Boddie) 10 ears were removed at random from each plot, totaling 1,000 ears per sample. Population fluctuation was related to the phenological stages of corn. For spatial behavior, the dispersion indices, frequency distribution models and geostatistics (Krigagem) were analyzed. The corn earworm (small and large) and corn-silk fly showed aggregate pattern and spatial behavior. The reach of caterpillars $<1 \mathrm{~cm}$ had an area of influence greater than caterpillars $>1 \mathrm{~cm}$, with spatial dependence being considered moderate. The corn-silk fly had a maximum area of influence of 1.33 ha with moderate and weak spatial dependence. The maps demonstrated that these insects occur dispersed throughout the corn area, but with aggregations influenced by the adjacent areas and edges of the crop. The largest occurrence of corn earworms was at the R3 stage. It was also found that the corn-silk fly followed the occurrence of the corn earworm. It is concluded that the studied pests have an aggregate spatial tendency in the corn crop and with the influence of adjacent areas, in addition to presenting related population peaks in the reproductive period of the corn crop.
\end{abstract}

Keywords: Aggregate; Corn-silk fly; Corn earworm; Geostatistics, Population fluctuation. $\square$ he corn (Zea mays L.) is important in world agricultural production, due to its widespread use, such as for human and animal food, even the production of biofuels. Brazil has an area of approximately 17 million hectares with production of more than 92 million tons and occupies the third place in world production (CONAB 2019). Therefore, the use of extensive areas allows pests to appear on crops, which causes losses to the producer (VENÂNCIO \& COSTA 2012).

There are several insects that affect the corn crop, the corn earworm [Helicoverpa zea (Boddie)] and the corn-silk fly of the genus Euxesta (Diptera: Otitidae) can cause injuries to the ear and become potential pests. Both pests oviposit in stigmastyles, interfering with pollination and grain formation, due to their mode of feeding (CRUz et al. 2011a).

The attack of $H$. zea starts in the stigmas, which compromises fertilization, the caterpillar penetrates the ear epically to consume the milky grains, leaving holes that facilitate the entry of microorganisms that cause diseases to the plant (Goyal et al. 2012; Valicente 2015).

The appearance of stigmas-style and the filling of grains leads to an increase in the population of Euxesta, indicating that the insect has the potential for a key pest in areas of commercial corn production (CRUz et al. 2011a). This fly has an intense movement of opening and closing its wings when walking. In the larval phase, it can cause injuries and damage to the ears, causing losses in productivity. At this stage, the larvae feed on the grains during their development, which can cause direct and indirect damage by facilitating the entry and colonization of microorganisms (LIMA et al. 2016).

It is necessary to know what factors can influence the management of insect pests, so it is important to know the spatial and temporal behavior and carry out sampling correctly. Geostatistical analyzes have shown adequate responses to the spatial behavior of insect pests, in addition to providing an understanding of insect interpolation and dispersion, facilitating the application of management practices (DAL PRÁ et al. 2011; DIONISIO et al. 2016).

Insects have variations in space and time, and analyzing this population dynamics, together with the influence of biotic and abiotic factors in agricultural ecosystems, makes it possible to infer the greatest occurrence preference, as well as to determine the main factors involved in this occurrence (ENNIS \& PHILPOTT 2019).

Therefore, this study aimed to verify the pattern and the spatial and temporal behavior of the corn earworm $(H . z e a)$ and corn-silk flies (Euxesta spp.) in the corn crop in IgarapéAçu, Northeast Pará, Eastern Amazon. 


\section{MATERIAL AND METHODS}

The study was conducted at the Experimental Farm of Igarapé-Açu - FEIGA (0107'33" South and 47037'27" West, $39 \mathrm{~m})$, municipality of Igarapé-Açu - PA, belonging to the Universidade Federal Rural da Amazônia - UFRA. The region has soil with a predominance of dystrophic Yellow Argisol with sandy texture (Guerino et al. 2017). The climate is defined as Ami, with an average annual rainfall of $2,500 \mathrm{~mm}$ and an average annual temperature of $25^{\circ} \mathrm{C}$, according to the Köppen classification.

The area used for the implantation of the study was of $10,000 \mathrm{~m}^{2}$ (1.0 ha) divided into 100 plots of $100 \mathrm{~m}^{2}(10 \mathrm{~m} x$ $10 \mathrm{~m})$, with adjacent areas composed by an experimental area of grassland, Megathyrsus maximus (Jacq.) BK Simon \& SWL Jacobs (0.6 ha); mango agroecosystem, Mangifera indica L. (1.7 ha); and fragments of secondary forest. The hybrid corn Priorizi M274 Morumbi was used, with an early cycle that presents rusticity and tolerance to the main corn diseases; with the aid of a seeder-fertilizer, it was sown without chemical control for insects, with a spacing of 0.90 $\mathrm{m}$ between rows and $0.15 \mathrm{~m}$ between plants. Sampling was carried out weekly, randomly selecting 10 plants per plot, for a total of 1,000 plants/sampling.

To evaluate Euxesta spp. the presence of adults in all parts of the plants was visualized, the number of individuals per plot was noted, from April 16 to June 25, 2016, starting the visualization seven days after the emergency (DAE).

To check for the presence of the $H$. zea caterpillar, sampling started at the reproductive stage of corn R2 (56 DAE), 10 ears of corn were randomly removed per plot with a total of 1,000 ears/samples, afterwards the material was sent to the Biodiversity Laboratory the UFRA Capanema campus.

In the laboratory, the husks of the ears were removed, the occurrence was visually analyzed in all parts of the ear, mainly in the ear tip and in the corn silks, and the number of caterpillars per plot was noted. To verify the spatial behavior of the different stages of development of the caterpillars, these were separated into small $(<1 \mathrm{~cm})$ and large $(>1$ $\mathrm{cm}$ ) caterpillars, there were four evaluations during the reproductive period that corresponded to the period from 04 to 25 June 2016.

To determine the temporal distribution, the total values of the individuals sampled over time were plotted, and related to the phenological stages of corn to determine which stage with the highest occurrence of insects. For the phenological stages of corn, it was considered the predominant stage in most plants on the sampling day. Phenological stages were considered according to the name and description of the study by WEISMANN (2008).

The spatial distribution pattern was analyzed by dispersion indices, and adjustment to the probabilistic models of frequency distribution. For this, the mean $(\widehat{m})$ and variance $\left(\mathrm{s}^{2}\right)$ were analyzed, and later the dispersion indices were

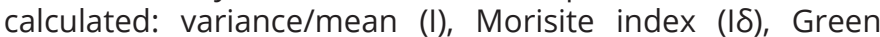
coefficient $(C X)$ and $K$ exponent of negative binomial distribution (k). The randomness deviation was tested by the chi-square test for variance / mean and Morisite index. The data were also tested for Poisson distribution and negative binomial distribution.

To verify the spatial behavior and influence of adjacent areas, geostatistical analysis was used with the application of kriging maps. The data were analyzed using semivariogram modeling. In models with landing, $\mathrm{CO}$ is the nugget effect, CO $+C 1$ is the landing, and ' $a$ ' is the range of the semivariogram.
The tested models were: spherical model, exponential model, Gaussian model and random model (nugget effect).

Subsequently, Kriging interpolation maps were constructed, showing the observed frequency values and the interpolation between the values. The R software for Windows was used to obtain semivariograms and kriging maps. The semivariogram function is used in geostatistics to express spatial variability in a predefined direction (STURARO 2015). To adjust the semivariogram models, the maximum likelihood method was used. The Akaike criterion (AIC) was used to select the most appropriate model, that is, the model with the lowest AIC was selected.

In this study, the Spatial Dependency Index (SDI) was also evaluated through the result calculated by the $\mathrm{k}$ index $\left(\mathrm{k}=\mathrm{C}_{0} / \mathrm{C}_{0}+\mathrm{C}_{1}\right)$ in which $\mathrm{k}$ values $<0.25$ are considered strong dependencies, $0.25 \leq k \geq 0.75$ is considered moderate dependence and, of $k>0.75$, there is weak spatial dependence (BAstos et al. 2019).

\section{RESULTS AND DISCUSSION}

For Euxesta spp. a total of 165 individuals were observed throughout the sampling period. There was a low occurrence of adults of corn-silk flies until the beginning of the tassel stage (VT $49 \mathrm{DAE}$ ), from the reproductive period (R2) with $56 \mathrm{DAE}$, an increase in those of adults of corn-silk fly was observed. The highest occurrence was verified on the last day of sampling with 48 dipterans already in the R5 stage (Table 1). CRuz et al. (2011 b) reported that adults from Euxesta have been found in the corn crop since the early stages, with a significant increase during the reproductive stages R1 and R2. The attraction of adults from Euxesta to ears attacked by other pests can be related to the attractiveness of this fly by volatile semiochemicals (Owens et al. 2017).

For this study, 4,000 ears of corn were analyzed, a total of 2,755 individuals of $\mathrm{H}$. zea was observed, corresponding to $68.88 \%$ of the ears sampled with infestation (Table 1 ). In the reproductive period ( $R 2)$ there was a predominance of small caterpillars $<1 \mathrm{~cm}$ (672 caterpillars), but in this period also caterpillars $>1 \mathrm{~cm}$ were observed, demonstrating that since the appearance of the style-stigmas oviposition should occur.

According to the development of corn, there was a greater observation of caterpillars $>1 \mathrm{~cm}$ at the stage of R3 (Table $1)$. The highest incidence of caterpillars occurred exactly in the kernel milky stage R3 with 847 ears infested out of a total of one thousand, corresponding to $84.70 \%$ of ears. These infestations decreased in the following samples, being $53.50 \%$ in R4 and $61.60 \%$ in R5. There are several factors that can decrease the occurrence of $H$. zea, among them climatic factors and natural enemies (OLMSTEAD et al. 2016).

The behavior of $\mathrm{H}$. zea was analyzed separately for small caterpillars $(<1 \mathrm{~cm})$ and large caterpillars $(>1 \mathrm{~cm})$ allowing results for better management strategies. Caterpillars $<1$ $\mathrm{cm}$ when submitted to the variance/mean ratio (I) and the Morisite index $(I \delta)$ showed an aggregate behavior. Having the Chi-square $\left(\chi^{2}=1 ; \mid \delta\right)$ significant at $5 \%$, proving the departure from randomness and confirming the aggregation of the sampled individuals.

Green Coefficient (Cx) values indicated contagious distribution. The values of $\mathrm{K}(\mathrm{K}$ mom) confirmed aggregation of corn earworms, verified on the dates 04 and 06/25/2016 positive values and less than two, suggesting a highly aggregated behavior, already for the dates 11 and 06/18/2016 this parameter indicates moderate aggregation.

For $H$. zea $>1 \mathrm{~cm}$, the distribution pattern verified by the 
Table 1. Occurrence of Helicoverpa zea caterpillars and adults of the corn-silk fly sampled in the corn crop during 2016, in Igarapé-Açu, Pará, Brazil.

\begin{tabular}{|c|c|c|c|c|c|c|c|}
\hline Dates & DAE & $\begin{array}{l}\text { Corn } \\
\text { stages }\end{array}$ & $\begin{array}{l}\text { H. zea } \\
<1 \mathrm{~cm}\end{array}$ & $\begin{array}{l}\text { H. zea } \\
>1 \mathrm{~cm}\end{array}$ & $\begin{array}{c}\text { Total } \\
\text { Helicoverpa }\end{array}$ & Infestation \% & $\begin{array}{l}\text { Adults Euxesta } \\
\text { spp. }\end{array}$ \\
\hline 04/16/2016 & 7 & V1 & 0 & 0 & 0 & 0 & 6 \\
\hline $04 / 23 / 2016$ & 14 & V3 & 0 & 0 & 0 & 0 & 1 \\
\hline 04/30/2016 & 21 & V6 & 0 & 0 & 0 & 0 & 5 \\
\hline 05/06/2016 & 27 & V7 & 0 & 0 & 0 & 0 & 0 \\
\hline $05 / 14 / 2016$ & 35 & V8 & 0 & 0 & 0 & 0 & 6 \\
\hline 05/21/2016 & 42 & V9 & 0 & 0 & 0 & 0 & 3 \\
\hline 05/28/2016 & 49 & VT & 0 & 0 & 0 & 0 & 9 \\
\hline 06/04/2016 & 56 & $\mathrm{R} 2$ & 672 & 85 & 757 & 75.70 & 34 \\
\hline 06/11/2016 & 63 & R3 & 423 & 424 & 847 & 84.70 & 30 \\
\hline 06/18/2016 & 70 & R4 & 153 & 382 & 535 & 53.50 & 23 \\
\hline 06/25/2016 & 77 & R5 & 162 & 454 & 616 & 61.60 & 48 \\
\hline Total & & & 1.410 & 1.345 & 2.755 & 68.88 & 165 \\
\hline
\end{tabular}

DAE: dates after emergency. \% infestation $=($ total Helicoverpa*100)/total ears analyzed.

variance/mean ratio (I) was of the aggregate type, showing

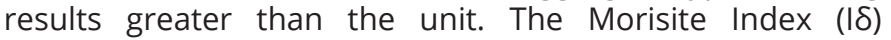
showed higher values than the unit indicating population aggregation or contagious type distribution. The Chi-square test for randomization $\left(\chi^{2}=l ; i \delta\right)$, shows the aggregation of individuals, so that all dates showed a $5 \%$ significance, excluding randomness. The Green Coefficient $(\mathrm{Cx})$, in turn, indicates a contagious type distribution and the $\mathrm{K}(\mathrm{K} \mathrm{mom})$ parameter confirmed aggregation, this parameter infers highly contagious aggregation for the dates of June 4,11 and 25,2016 , and moderate aggregation on 06/18/2016 (Table 2).

The spatial behavior of the aggregate type of caterpillars in agricultural corn crops tends to prevail, this aggregation behavior was observed in Southern Ethiopia with dispersion indexes for Busseola fusca Fuller (Lepidoptera: Noctuidae) (TADDELE et al. 2020), and in Spodoptera frugiperda (Smith) (Lepidoptera: Noctuidae) smaller than $1 \mathrm{~cm}$ (Rıos et al. 2014), caterpillars between 1 and $1.5 \mathrm{~cm}$ (Melo et al. 2014) and larger than $1.5 \mathrm{~cm}$ (Rıos et al. 2014). This aggregate behavior of corn earworm may be related to the appearance of stigmas-styles, FORESTl et al. (2013) found that the number of eggs of H. zea is high and follows the period of emission of ears and stylestigmas in the corn crop. So, according to the appearance of stigmas-styles in the plots, they tend to favor the aggregation and infestation of $H$. zea.

For the analysis of spatial distribution of Euxesta spp., the first sampling dates were discarded, due to the low occurrence. Therefore, the dispersion indices were analyzed from the VT stage on 05/28/2016. CRUz et al. (2011b) observed that the corn-silk fly occurred since the beginning of the corn crop. In this study, the occurrence of Euxesta has also occurred since the initial stages and these flies may have migrated from adjacent areas such as natural areas, pastures and cultivated with mango trees.

The spatial distribution of Euxesta spp. analyzed by the variance/average ratio (I) shows aggregate behavior, with all variances being higher than the means. The Morisita

Table 2. Means, variances and dispersion indices for the occurrence of corn earworm (Helicoverpa zea) in Igarapé-Açu, Pará, Brazil.

\begin{tabular}{|c|c|c|c|c|}
\hline $\begin{aligned} \text { Helicoverpa zea }< & 1 \mathrm{~cm} \\
& \text { Indexes }\end{aligned}$ & $06 / 04 / 2016$ & $06 / 11 / 2016$ & $06 / 18 / 2016$ & $06 / 25 / 2016$ \\
\hline M & 6.72 & 4.23 & 1.53 & 1.62 \\
\hline$s^{2}$ & 605.07 & 127.85 & 22.52 & 67.03 \\
\hline $\mathrm{I}=\mathrm{s}^{2} / \mathrm{m}$ & 9.00 & 30.22 & 14.72 & 41.37 \\
\hline $1 \delta$ & 21.81 & 14.75 & 13.07 & 29.29 \\
\hline$X^{2}=1 ; 1 \delta$ & 891.39* & $299.22 *$ & $145.69 *$ & $409.61 *$ \\
\hline $\mathrm{K}$ mom & 0.84 & 20.92 & 3.24 & 0.52 \\
\hline$C x$ & 0.01 & 0.00 & 0.00 & 0.02 \\
\hline $\begin{aligned} \text { Helicoverpa zea }> & 1 \mathrm{~cm} \\
& \text { Indexes }\end{aligned}$ & $06 / 04 / 2016$ & $06 / 11 / 2016$ & 06/18/2016 & $06 / 25 / 2016$ \\
\hline M & 0.85 & 4.24 & 3.82 & 4.54 \\
\hline$s^{2}$ & 17.65 & 310.33 & 60.89 & 233.82 \\
\hline $\mathrm{I}=\mathrm{s}^{2} / \mathrm{m}$ & 20.77 & 7.32 & 15.94 & 51.50 \\
\hline $1 \delta$ & 22.69 & 24.79 & 11.54 & 1.91 \\
\hline$X^{2}=1 ; 1 \delta$ & $205.58^{*}$ & $724.59 *$ & $157.79 *$ & $509.88^{*}$ \\
\hline $\mathrm{k} \mathrm{mom}$ & 0.79 & 0.67 & 64.33 & 10.94 \\
\hline$C x$ & 0.01 & 0.01 & 0.00 & 0.01 \\
\hline
\end{tabular}

$\mathrm{m}=$ sample mean; $\mathrm{s}^{2}=$ variance; $\mathrm{I}=$ variance/mean ratio; $I \delta=$ Morisite index; $\mathrm{X}^{2} \mathrm{I}=$ chi-square test to deviate randomness from the variance $/$ mean ratio; $X^{2} I \delta=$ chi-square test for deviating from the randomness of the Morisita index; $\mathrm{k}$ mom = $\mathrm{k}$ calculated by the method of moments; Cx $=$ Green's coefficient; * = Significant at 5\% probability; NS = Not significant at 5\% probability. 
Index (Iס) presented values higher than the unit, indicating contagious behavior, as demonstrated by the Chi-square test $\left(\chi^{2}=1 ; \mid \delta\right)$, where the results were significant at $5 \%$. The Green Coefficient $(C x)$ varied between positive values and less than 1 , considered an aggregate distribution. The parameter of $k$ ( $\mathrm{k}$ mom) showed positive values and $<2$, a tendency to high aggregation (Table 3 ). The aggregate occurrence of ear flies was related to the appearance of stigmatic styles in the plots and also to the occurrence of corn earworm.

In Table 4, it was observed that the sampling data of small and large caterpillars adjusted on two dates to the negative binomial model, not adjusting to the Poisson model, confirming the tendency of aggregation of caterpillars. Similar behavior was observed in a study with adults of Bemisia tabaci (Gennadius) (Hemiptera: Aleyrodidae) and Aphis gossypii Glover (Hemiptera: Aphididae) in cotton crop, which did not fit the negative binomial model at all times (RODRIGUEs et al. 2010).

When the adjustments to the Poisson and negative bionomial models were tested for the distribution of Euxesta spp., it was found that both models showed adjustments, with three dates each model (Table 5). These adjustment results for both models tested, are probably due to the low number of flies occurring, leaving the analyzes with low degree of freedom values.

Using $\mathrm{R}^{2}$ as a parameter in geostatistical analyzes, he verified the spatial distribution of the aggregated type, adjusting to the spherical model on three dates for $H$. zea $<1 \mathrm{~cm}$. The spatial dependency index $(k)$ was of the moderate type. On the second sampling date, a pure nugget effect was observed, showing a tendency towards the random distribution of $H$. zea in this sample (Table 6). The maximum distance between the samples or the maximum range found in the samples ranged from 23.39 to 71.37 meters with an area of influence from 0.17 ha to 1.6 ha (Table 6). The analyzed data allowed to estimate the influence of the aggregation points of the corn earworms and their infestation in the experimental area of the corn crop.

The spherical model, presents itself as more adequate to exemplify the spatial behavior of insects. MACHADO et al. (2015) found in the spherical model with moderate spatial dependence for Helicoverpa armigera (Hübner) (Lepidoptera: Noctuidae), and Chrysodexis includens (Walker) (Lepidoptera: Noctuidae), in soybean crop. A similar result was observed in the spatial distribution of the coffee borer Hypothenemus hampei (Ferrari) (Coleoptera: Scolytidae) in coffee conilon, with data adjusted to the spherical model and moderate spatial dependence (SILva et al. 2017).

The data from the $H$. zea caterpillar $>1 \mathrm{~cm}$, shows adjustment to three models, with the Gaussian model standing out with adjustment in two of the four evaluations. The moderate spatial dependency index prevailed on all dates analyzed (Table 6). Similar spatial distribution was found by SANTI et al. (2014), when they evaluated the spatiotemporal distribution of Anticarsia gemmatalis Hübner (Lepidoptera: Noctuidae) and C. includens in soybean crop, where they occurred aggregates in the area, with moderate spatial dependence.

The maximum range for $H$. zea was obtained on 11/06/2016 with 43.33 meters and 0.59 ha of area of influence, whereas the minimum range was found on the first sampled date with

Table 3. Means, variances and dispersion indices for the occurrence of corn-silk fly (Euxesta spp.) in Igarapé-Açu, Pará, Brazil.

\begin{tabular}{|c|c|c|c|c|c|}
\hline \multicolumn{6}{|c|}{ Euxesta spp. } \\
\hline Indexes & $05 / 28 / 2016$ & $06 / 04 / 2016$ & $06 / 11 / 2016$ & $06 / 18 / 2016$ & $06 / 25 / 2016$ \\
\hline M & 0.09 & 0.34 & 0.30 & 0.23 & 0.48 \\
\hline$s^{2}$ & 0.14 & 0.51 & 0.45 & 0.26 & 0.66 \\
\hline $\mathrm{I}=\mathrm{s}^{2} / \mathrm{m}$ & 15.93 & 14.99 & 15.15 & 11.29 & 1.37 \\
\hline $\mid \delta$ & 83.33 & 24.96 & 27.59 & 1.58 & 1.77 \\
\hline$X^{2}=1 ; 1 \delta$ & $157.67^{\star}$ & $148.35^{*}$ & $150.00 *$ & $111.78 *$ & $135.33 *$ \\
\hline $\mathrm{K}$ mom & 0.15 & 0.68 & 0.58 & 17.81 & 13.08 \\
\hline$C x$ & 0.07 & 0.02 & 0.02 & 0.01 & 0.01 \\
\hline
\end{tabular}

$\mathrm{m}=$ sample mean; $\mathrm{s}^{2}=$ variance; $\mathrm{I}=$ variance/mean ratio; $I \delta=$ Morisite index; $\mathrm{X}^{2} \mathrm{I}=$ chi-square test to deviate randomness from the variance $/$ mean ratio; $X^{2} I \delta=$ chi-square test for deviating from the randomness of the Morisita index; $\mathrm{k}$ mom = $\mathrm{k}$ calculated by the method of moments; $C x=$ Green's coefficient; * = Significant at 5\% probability; NS = Not significant at 5\% probability.

Table 4. Results of the chi-square test to adjust the Poisson distributions, and Binomial negative to data from Helicoverpa zea $<1 \mathrm{~cm}$ and Helicoverpa zea $>1 \mathrm{~cm}$.

\begin{tabular}{|c|c|c|c|c|c|c|}
\hline \multirow{2}{*}{ Dates } & \multicolumn{3}{|c|}{ Poisson } & \multicolumn{3}{|c|}{ Binomial Negative } \\
\hline & $\mathbf{X}^{2}$ & df & $\mathbf{P}$ & $\mathrm{X}^{2}$ & df & $\mathbf{P}$ \\
\hline \multicolumn{7}{|c|}{ Helicoverpa zea $<1 \mathrm{~cm}$} \\
\hline $06 / 04 / 2016$ & $1132,0155^{* *}$ & 12 & 0,0000 & $42,7848 * \star$ & 16 & 0,0003 \\
\hline $06 / 11 / 2016$ & $77,0874 * *$ & 8 & 0,0000 & $13,0656^{\text {NS }}$ & 10 & 0,2200 \\
\hline $06 / 18 / 2016$ & $15,0287^{* *}$ & 4 & 0,0046 & $6,5730^{\mathrm{NS}}$ & 4 & 0,1603 \\
\hline $06 / 25 / 2016$ & $28,7190 * *$ & 4 & 0,0000 & $18,5443^{* *}$ & 6 & 0,0050 \\
\hline \multicolumn{7}{|c|}{ Helicoverpa zea $>1 \mathrm{~cm}$} \\
\hline 06/04/2016 & $17,8600 * *$ & 2 & 0,0001 & $4,6645^{\mathrm{NS}}$ & 3 & 0,1981 \\
\hline $06 / 11 / 2016$ & $157,9057 * \star$ & 8 & 0,0000 & $36,9526 * *$ & 12 & 0,0002 \\
\hline $06 / 18 / 2016$ & $23,0417 * \star$ & 8 & 0,0033 & $157,7906^{\mathrm{NS}}$ & 8 & 0,3577 \\
\hline $06 / 25 / 2016$ & $66,1437 * *$ & 9 & 0,0000 & $42,5626^{\star *}$ & 12 & 0,0000 \\
\hline
\end{tabular}

$\mathrm{X}^{2}=$ Chi-square test statistics; $\mathrm{df}=$ number of degrees of freedom of the chi-square; $\mathrm{p}=$ level of probability of the chi-square test; * Significant at 5\% probability; ** Significant at 1\% probability; NS Not significant at 5\% probability; IDF = insufficient number of degrees of freedom. 
Table 5. Results of the chi-square test to adjust the Poisson distributions, and Binomial negative to data from Euxesta spp.

\begin{tabular}{|c|c|c|c|c|c|c|}
\hline \multirow{2}{*}{ Dates } & \multicolumn{3}{|c|}{ Poisson } & \multicolumn{3}{|c|}{ Binomial negative } \\
\hline & $\mathrm{X}^{2}$ & Df & $\mathbf{P}$ & $\mathrm{X}^{2}$ & df & $\mathbf{P}$ \\
\hline 05/28/2016 & IDF & IDF & IDF & IDF & IDF & IDF \\
\hline 06/04/2016 & $2,4998^{\mathrm{NS}}$ & 1 & 0,1139 & $0,5640^{\text {NS }}$ & 1 & 0.4526 \\
\hline $06 / 11 / 2016$ & $2,8053^{\mathrm{NS}}$ & 1 & 0,0940 & $1,2171^{\mathrm{NS}}$ & 1 & 0.2699 \\
\hline 06/18/2016 & $1,9303^{\mathrm{NS}}$ & 1 & 0,1647 & IDF & IDF & IDF \\
\hline $06 / 25 / 2016$ & $13,2179 * *$ & 2 & 0,0013 & $2,0229^{\mathrm{NS}}$ & 1 & 0.1549 \\
\hline
\end{tabular}

$\mathrm{X}^{2}=$ Chi-square test statistics; $\mathrm{df}=$ number of degrees of freedom of the chi-square; $\mathrm{p}=$ level of probability of the chi-square test; * Significant at 5\% probability; ** Significant at 1\% probability; NS Not significant at 5\% probability; IDF = insufficient number of degrees of freedom.

Table 6. Semivariogram parameters, area of reach, coefficient of determination $\left(R^{2}\right)$, spatial dependency index and experimental model for geostatistical analysis of Helicoverpa zea $<1 \mathrm{~cm}$ and Helicoverpa zea $>1 \mathrm{~cm}$ in one hectare of corn crop.

\begin{tabular}{|c|c|c|c|c|c|c|c|}
\hline \multicolumn{8}{|c|}{ Helicoverpa zea $<1 \mathrm{~cm}$} \\
\hline \multirow[t]{2}{*}{ Analysis dates } & \multicolumn{3}{|c|}{ Semivariogram parameters } & \multirow{2}{*}{ Models } & \multirow{2}{*}{$\mathbf{R}^{\mathbf{2}}$} & \multirow{2}{*}{ Area (ha) } & \multirow{2}{*}{$\mathbf{K}$} \\
\hline & $c_{0}$ & $c_{1}$ & $a(m)$ & & & & \\
\hline 06/04/2016 & 0.06 & 0.04 & 71.37 & Spherical & 0.94 & 1.60 & Moderate \\
\hline 06/11/2016 & \multicolumn{7}{|c|}{ Random } \\
\hline 06/18/2016 & 0.10 & 0.12 & 23.39 & Spherical & 0.98 & 0.17 & Moderate \\
\hline 06/25/2016 & 0.17 & 0.06 & 28.39 & Spherical & 0.99 & 0.25 & Moderate \\
\hline \multicolumn{8}{|c|}{ Helicoverpa zea $>1 \mathrm{~cm}$} \\
\hline \multirow[t]{2}{*}{ Analysis dates } & \multicolumn{3}{|c|}{ Semivariogram parameters } & \multirow{2}{*}{ Models } & \multirow{2}{*}{$\mathbf{R}^{2}$} & \multirow{2}{*}{ Area (ha) } & \multirow{2}{*}{$\mathbf{K}$} \\
\hline & $c_{0}$ & $c_{1}$ & $a(m)$ & & & & \\
\hline 06/04/2016 & 0.16 & 0.09 & 20.56 & Gaussian & 0.99 & 0.13 & Moderate \\
\hline 06/11/2016 & 0.04 & 0.07 & 43.33 & Gaussian & 0.97 & 0.59 & Moderate \\
\hline 06/18/2016 & 0.04 & 0.04 & 30.08 & Exponential & 0.97 & 0.28 & Moderate \\
\hline 06/25/2016 & 0.05 & 0.03 & 39.27 & Spherical & 0.97 & 0.48 & Moderate \\
\hline
\end{tabular}

$\mathrm{C}_{0}$ : nugget effect; $\mathrm{C}_{1}$ : contribution; a: reach $(\mathrm{m}) ; \mathrm{K}$ : spatial dependency index; Area calculated by $\pi r^{2}$, where $\pi=3.14 \mathrm{and} r=a\left(1 \mathrm{ha}=10,000^{2}\right)$; $\mathrm{K}=\mathrm{C}_{0} / \mathrm{C}_{0}+\mathrm{C}_{1}$.

20.56 meters and 0.13 ha of reach area (Table 6). The range demonstrates the distance at which the samples correlate within space (OliveIRA \& ANTôNIO 2017). The range results are important, because they demonstrate the influence of infested areas on the rest of the area, it is noted that smaller caterpillars tended to reach larger areas in relation to large caterpillars, showing the relevance of controlling this caterpillar early in the detection.

The $H$. zea adults can disperse over great distances (OLMSTEAD et al. 2016) which can facilitate the distribution of eggs and consequently a greater range of distribution for small caterpillars. On the other hand, eggs and small caterpillars are more susceptible to the action of biotic and abiotic controllers (OLMSTEAD et al. 2016), perhaps justifying the aggregation with less distribution of larger caterpillars that are concentrated in more favorable areas.

For the corn-silk fly, semivariograms were better adjusted by the spherical model, fitting into five evaluations. The spatial dependence alternated between weak and moderate, the range obtained varied from 13.62 to $65.20 \mathrm{~m}$ with a maximum area of influence of 1.33 ha (Table 7). The corn-silk fly tends to increase the area of reach depending on its incidence, on the dates of greatest occurrence were the largest ranges. The pure nugget effect seen on two dates shows the randomness and non-spatial dependence on dates of low occurrence of this fly. Euxesta eggs and larvae are found with aggregation in reproductive stages of corn (KALSI et al. 2014), this immature aggregation may reflect the aggregate behavior of adults.

Krigagem maps of $H$. zea $<1 \mathrm{~cm}$ showed aggregations distributed throughout the corn crop area. On the first date analyzed, the concentration is mostly close to the edges with adjacent pasture areas. NGUYEN \& NANSEN (2018) report that the edges and adjacencies of agricultural areas influence the distribution of insects, largely caused by abiotic and biotic factors. The distribution of $H$. zea started with migrations from the edges with pasture to corn, this area was open without high barriers as in other areas adjacent to the corn crop.

On the second date, the caterpillar occurred with aggregations at the edges and centralized in the study area, on the last analysis date the caterpillar presented aggregations concentrated in the central region of the area (Figure 1). According to MACHADO et al. (2015) the abundance of caterpillars is a decisive factor for its dispersion in the field, since, with the population peak, the spatial dependence in the samples will decrease.

Looking at maps referring to $H$. zea $>1 \mathrm{~cm}$, results similar to that of small caterpillars are observed. The plots on the edges have high concentrations and centralized colonization may be due to dispersion. The mango agroecosystem may be influencing as a physical barrier to pests, since the concentration and aggregation occurred less in the areas close to the mango crop (Figure 2).

The edges and adjacent plants of agricultural areas can interfere with the distribution of insect communities. These environments function as natural or artificial barriers that affect insect mobility and dispersion (NGUYEN \& NANSEN 2018; PENN 2018). The trees on the margins of agricultural areas act as windbreaks, preventing the dispersion of insects that need the wind to colonize these agricultural areas (NGUYEN \& NANSEN 2018). The maps also help to verify the uniformity of 
Table 7. Semivariogram parameters, area of reach, coefficient of determination $\left(\mathrm{R}^{2}\right)$, spatial dependency index and experimental model for geostatistical analysis of Euxesta spp. in one hectare of corn crop.

\begin{tabular}{|c|c|c|c|c|c|c|c|}
\hline \multirow{2}{*}{ Analysis dates } & \multicolumn{3}{|c|}{ Semivariogram parameters } & \multirow{2}{*}{ Models } & \multirow{2}{*}{$\mathbf{R}^{2}$} & \multirow{2}{*}{ Area (ha) } & \multirow{2}{*}{$\mathbf{K}$} \\
\hline & $C_{0}$ & $c_{1}$ & $a(m)$ & & & & \\
\hline $04 / 16 / 2016$ & 0.03 & 0.03 & 13.62 & Gaussian & 0.97 & 0.06 & Moderate \\
\hline $04 / 23 / 2016$ & & & & Random & & & \\
\hline 04/30/2016 & & & & Random & & & \\
\hline $05 / 14 / 2016$ & 0.02 & 0.04 & 17.78 & Spherical & 0.87 & 0.10 & Moderate \\
\hline $05 / 21 / 2016$ & 0.01 & 0.02 & 18.77 & Gaussian & 0.91 & 0.11 & Moderate \\
\hline $05 / 28 / 2016$ & 0.06 & 0.01 & 47.84 & Spherical & 0.88 & 0.72 & Weak \\
\hline $06 / 4 / 2016$ & 0.12 & 0.07 & 65.20 & Spherical & 0.92 & 1.33 & Moderate \\
\hline $06 / 11 / 2016$ & 0.10 & 0.06 & 23.84 & Spherical & 0.97 & 0.18 & Moderate \\
\hline $06 / 18 / 2016$ & 0.15 & 0.01 & 54.78 & Spherical & 0.99 & 0.94 & Weak \\
\hline $06 / 25 / 2016$ & 0.19 & 0.03 & 45.95 & Gaussian & 0.99 & 0.66 & Weak \\
\hline
\end{tabular}

$\mathrm{C}_{0}$ : nugget effect; $\mathrm{C}_{1}$ : contribution; a: reach $(\mathrm{m}) ; \mathrm{K}$ : spatial dependency index; Area calculated by $\pi \mathrm{r}^{2}$, where $\pi=3.14$ and $r=a\left(1 \mathrm{ha}=10,000^{2}\right)$; $\mathrm{K}=\mathrm{C}_{0} / \mathrm{C}_{0}+\mathrm{C}_{1}$.

the infestation on dates with high occurrence.

On the maps of Euxesta spp. demonstrate the aggregations, confirming the results of the dispersion analyzes. The cornsilk flies started occurring in the area close to the mango agroecosystem and in the secondary forest fragment area, dispersing to the center of the corn crop. On the following dates (05/28 and 06/04 of 2016) the aggregations were concentrated in the center of the corn crop, and the last analyzes showed that the spatial distribution of corn-silk flies followed the spatial distribution of corn earworms (Figure 3). The corn-silk fly shows an opportunistic behavior benefiting from the attack of other insects on the ear (MOREIRA \& ARAGÃO 2009), the adults of Euxesta spp. demonstrated, through aggregations, that they were influenced and attracted by plants that had ears with the presence of $H$. zea caterpillars.
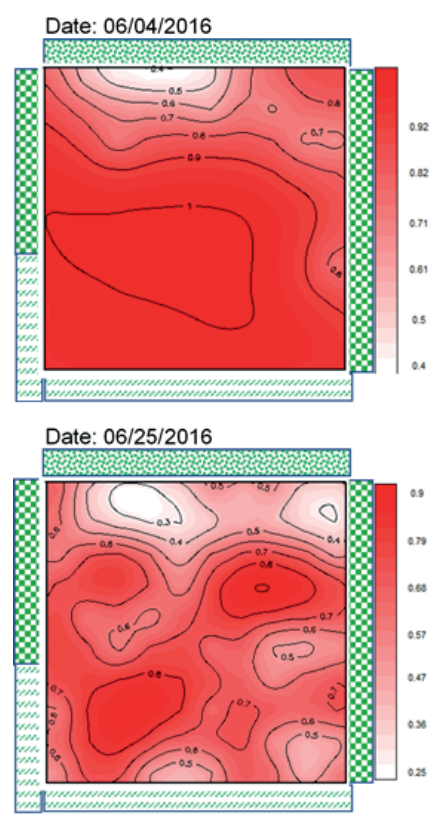

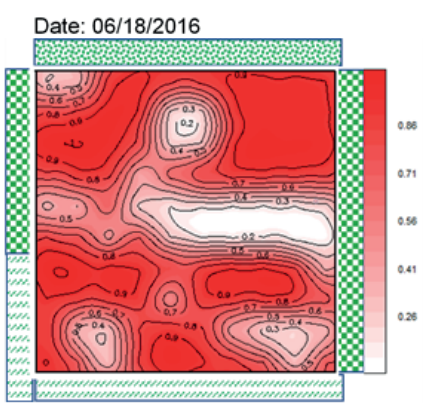

Figure 1. Maps of spatial distribution of Helicoverpa zea $<1 \mathrm{~cm}$ in the corn crop area with natural areas of secondary forest fragment, pasture and adjacent mango agroecosystem in Igarapé-Açu, Pará, Brazil. Darkening indicates a higher density of insects.

\section{Pasture 3 Forest fragment Mango agroecosystem}

When verifying the population fluctuation of $\mathrm{H}$. zea it was observed on 06/04/2016 (stage R2, kernel blister stage) the caterpillars $<1 \mathrm{~cm}$ presented a total of 672 individuals, while the caterpillars $>1 \mathrm{~cm}$ presented 85 . In the R3 kernel milky stage $(06 / 11 / 2016)$ amount of $H$. zea $<1 \mathrm{~cm}$ and $>1 \mathrm{~cm}$ were 423 and 424 individuals, respectively. From this date on, the presence of caterpillars $<1 \mathrm{~cm}$ decreased and the occurrence of caterpillars $>1 \mathrm{~cm}$ increased, with a population peak of 454 individuals in stage R5, kernel dent stage (Figure 4). 
adults are found at all stages of corn development, but there is an increase in the population with the appearance of stigma-styles.

Both H. zea and Euxesta flies exhibit aggregate spatial behavior during the reproductive stage of corn. However, caterpillars $<1 \mathrm{~cm}$ have a greater reach and area of influence than caterpillars $>1 \mathrm{~cm}$, with spatial dependence being considered moderate. The corn-silk fly has a maximum area of influence of 1.33 ha and with moderate and weak spatial dependence.

Kriging maps demonstrate that these insects can occur throughout the corn area, but with aggregations mainly influenced by the adjacent areas and edges of the crop.
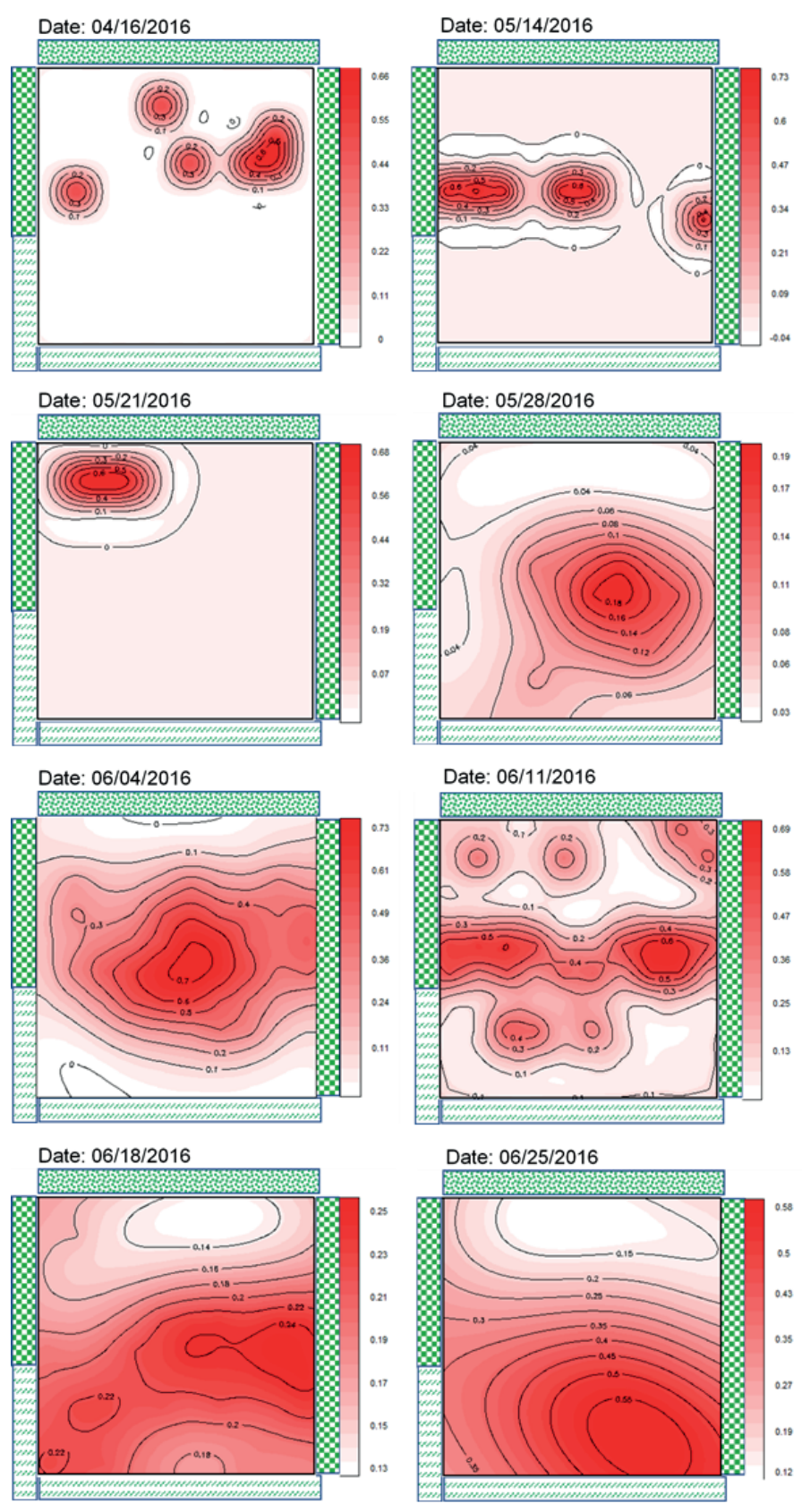

Pasture Forest fragment Mango agroecosystem

Figure 3. Maps of spatial distribution of Euxesta spp. in the corn crop area with natural areas of secondary forest fragment, pasture and adjacent mango agroecosystem in Igarapé-Açu, Pará, Brazil. Darkening indicates a higher density of insects.

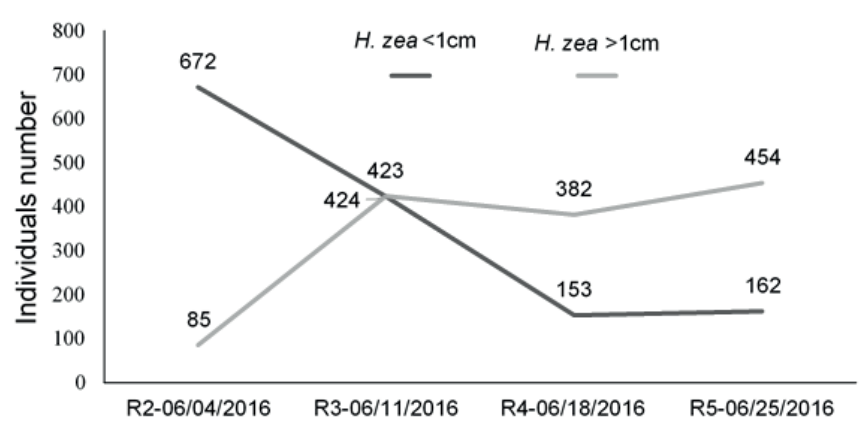

Figure 4. Population fluctuation and the relationship between the phenological stages of the corn crop and the Helicoverpa zea caterpillar, Igarapé-Açu, Pará, Brazil.

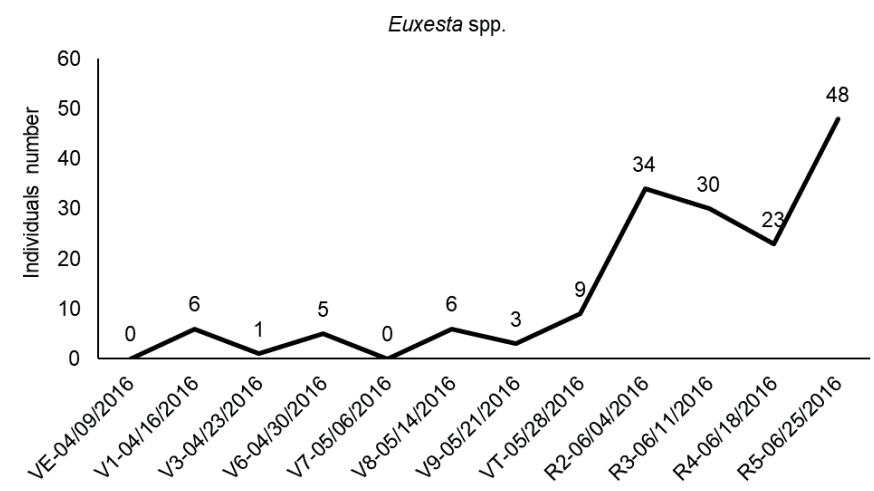

Figure 5. Population fluctuation and the relationship between the phenological stages of the corn crop and the Euxesta spp., IgarapéAçu, Pará, Brazil.

\section{ACKNOWLEDGEMENTS}

This research was funded by Conselho Nacional de Desenvolvimento Científico e Tecnológico (CNPq), which deserves our respect and acknowledgments.

\section{REFERENCE}

Bastos, LF, AVF dos Santos, FV Penner, LMM Siqueira, AG da Silva, ICF Martins, PMP Lins \& TFV Batista, 2019. Spatial Analysis and Population Dynamics of Haplaxius crudus (Hemiptera: Cixiidae) in Coconut Amazon. Journal of Agricultural Science, 11: 186-197. DOI: https://doi.org/10.5539/jas.v11n14p186

CONAB, 2019. Acompanhamento da Safra Brasileira: Grãos. Companhia Nacional de Abastecimento (CONAB), Brasília, Distrito Federal. Available on: <https://www.conab.gov. $\mathrm{br} / \mathrm{s}$.

Cruz, I, P Viana \& R Bianco, 2011b. Manejo integrado de pragas. Milho o produtor pergunta, a Embrapa responde, p. 171-192. In: Cruz, JC, PC Magalhães, IA Pereira Filho \& JAA Moreira (eds). EMBRAPA (Informação Tecnológica). Brasília, Distrito Federal.

Cruz, I, RB Silva, MLC Figueiredo, AM Penteado-Dias, MCL Del Sarto \& GS Nuessly, 2011a. Survey of ear flies (Diptera, Ulidiidae) in maize (Zea mays L.) and a newrecord of Euxesta mazorca Steyskalin Brazil. Revista Brasileira de Entomologia, 55: 102-108. DOI: https://doi.org/10.1590/ S0085-56262011000100016

Dal Prá, E, JVC Guedes, MA Cherman, AH Jung, SJP Silva \& GG Ribas, 2011. Uso da geoestatística para caracterização da distribuição espacial de larvas de Diloboderus abderus. Ciência Rural, 41: 1689-1694. DOI: https://doi.org/10.1590/ S0103-84782011001000020

Dionisio, LFS, ACS Lima, RM Izidório, AVF dos Santos, HM Orrillo \& GLC Lima, 2016. Monitoramento de insetos e distribuição 
espacial de Sitophilus spp. (Coleoptera: Curculionidae) em unidade de beneficiamento e armazenamento de grãos. Revista Agroambiente On-line, 10: 253-262. DOI: https://doi.org/10.18227/1982-8470ragro.v10i3.3273

Ennis, KK \& SM Philpott, 2019. Seasonal and microhabitat differences alter ant predation of a globally disruptive coffee pest. Agriculture, Ecosystems \& Environment, 284: 106597. https://doi.org/10.1016/j.agee.2019.106597

Foresti, J, O Bernardi, M Zart \& MS Garcia, 2013. Comportamento de Oviposição de Helicoverpa zea (Boddie, 1850) (Lepidoptera: Noctuidae) em Milho Semente e Simulação de Controle. Revista Brasileira de Milho e Sorgo, 12: 78-84. DOI: https://doi.org/10.18512/1980-6477/rbms. v12n1p78-84

Goyal, G, GS Nuessly, DR Seal, GJ Steck, JL Capinera \& KJ Boote, 2012. Alternative plants for development of picturewinged fly pests of maize. Entomologia Experimentalis et Applicata, 143: 177-184. DOI: https://doi.org/10.1111/ j.1570-7458.2012.01245.x

Guerino, RS, JÁ Lima, ALP Silva, PD Oliveira, ICF Martins, JF Brito Neto \& WLC Aviz, 2017. Poductive viability of sweet pepper ('Capsicum Chinense' [J.] CV. Lupita) using water management with diferente soil water tensions. Australian Journal of Crop Science, 11: 1651-1656. DOI: https://doi.org/10.21475/ajcs.17.11.12.pne895

Kalsi, M, DR Seal, GS Nuessly, JL Capinera \& CG Martin, 2014. Distribution of Arthropod Predators and their Responses to Euxesta spp. (Diptera: Ulidiidae) in the Laboratory and in Corn Fields in South Florida. Florida Entomologist, 97: 911 920. DOI: https://doi.org/10.1653/024.097.0349

Lima, BV, BD Caetano, GG de Souza, MT Spontoni \& LCD de Souza, 2016. Pragas da cultura do Milho. Revista Conexão Eletrônica, 13: 1-15.

Machado, MRR, DA Magano, DB Araldi, LP Amaral \& JVC Guedes. 2015. Emprego da geoestatística na distribuição espacial de lagartas presente na cultura da soja. Resumos 2236-2118. Em IV Simpósio de Geoestatística Aplicada em Ciências Agrárias-SGeA. Botucatu, São Paulo. DOI: https://doi.org/10.12702/IV-SGEA-a55

Melo, EP, PE Degrande, IS de Lima Júnior, R Suekane, C Kodama \& MG Fernandes, 2014. Disposição espacial e injúrias da lagarta-do-cartucho Spodoptera frugiperda (J. E. Smith) (Lepidoptera: Noctuidae) em milho. Revista Ceres, 61: 343-349. DOI: https://doi.org/10.1590/S0034737X2014000300007

Moreira, HJC \& FD Aragão, 2009. Manual de Pragas do Milho. Available on: <https://www.agrolink.com.br/downloads/ manual\%20de\%20pragas\%20do\%20milho.pdf>.

Nguyen, HDD \& C Nansen, 2018. Edge-biased distributions of insects. A review. Agronomy for Sustainable Development, 38: 11. DOI: https://doi.org/10.1007/s13593-018-0488-4

Oliveira, BR, \& GB Antônio, 2017. Modelagem geoestatística aplicada a geologia de engenharia. Boletim Paranaense de Geociências, 73: 46-53. DOI: https://doi.org/10.5380/geo. v73i1.43417

Olmstead, DL, BA Nault \& AM Shelton, 2016. Biology, Ecology, and Evolving Management of Helicoverpa zea (Lepidoptera:
Noctuidae) in Sweet Corn in the United States. Journal of Economic Entomology, 109: 1667-1676. DOI: https://doi.org/10.1093/jee/tow125

Owens, D, R Cherry, M Karounos \& GS Nuessly, 2017. Evaluation of Lures for Monitoring Silk Flies (Diptera: Ulidiidae) in Sweet Corn. Florida Entomologist, 100: 251256. DOI: https://doi.org/10.1653/024.100.0218

Penn, HJ, 2018. Wooded field margins increase potential for cultural and biological control of soybean pests. Agriculture, Ecosystems \& Environment, 255: 45-51. DOI: https://doi.org/10.1016/j.agee.2017.12.016

Rios, ÉS, ICF Martins, MP Noronha, JA Silva, JG Silva Filho \& CA Badji, 2014. Spatial distribution of Spodoptera frugiperda in the wasteland of southern Pernambuco state, Brazil. Revista de Ciências Agrárias Amazonian Journal of Agricultural and Environmental Sciences, 57: 297-304. DOI: https://doi.org/10.4322/rca.ao1461

Rodrigues, TR, MG Fernandes \& HR Santos, 2010. Distribuição espacial de Aphis gossypii (Glover) (Hemiptera, Aphididae) e Bemisia tabaci (Gennadius) biótipo B (Hemiptera, Aleyrodidae) em algodoeiro Bt e não-Bt. Revista Brasileira de Entomologia, 54:136-143. DOI: https://doi.org/10.1590/ S0085-56262010000100019

Santi, AL, MR Cherubin, CT Riffel, CJ Basso, JLF. Pires, LPD Flora, GM Corassa \& MT Eitelwein, 2014. Distribuição espaçotemporal de lagartas desfolhadoras e sua correlação com o rendimento de grãos na cultura da soja, p. 260-266. In: Bernarti, ACC, JM Naime, AV Resende, LH Bassoi \& RY Inamasu (Org.). Agricultura de precisão: resultado de um novo olhar. Brasília, Distrito Federal.

Silva, BSO, TT Herzog, MB da Silva, I Gontijo \& FL Partelli, 2017. Spatial Distribution of Coffee Berry Borerin Conilon Coffee. Coffee Science, 12: 526-533. DOI: https://doi.org/10.25186/cs.v12i4.1360

Sturaro, JR, 2015. Apostila de Geoestatística básica. Departamento de Geologia Aplicada (IGCE), Rio Claro, São Paulo. Available on: <https://igce.rc.unesp.br/Home/ Departamentos47/geologiaaplicada/apostila-basica.pdf>.

Taddele, A, F Azerefegne \& Beyene, 2020. Spatial distribution and sampling size for monitoring of African maize stem borer, Busseola fusca (Fuller) (Lepidoptera: Noctuidae) on maize (Zea mays L.) in Southern Ethiopia. African Journal of Agricultural Research, 15: 203-211. DOI: https://doi.org/10.5897/AJAR2019.14122

Valicente, FH, 2015. Manejo integrado de pragas na cultura do milho. Circular Técnica (INFOTECA-E). Embrapa Milho e Sorgo - Circular Técnica (INFOTECA-E). Sete Lagoas, Minas Gerais. Available on: <http://www.infoteca.cnptia. embrapa.br/infoteca/handle/doc/1017489>.

Venâncio, HL \& PJA Costa, 2012. Controle de pragas na cultura do milho. Acta Scientiarum Agronomy. Available on: DOI: https://doi.org/10.12702/IV-SGEA-a55.

Weismann, M, 2008. Fases de desenvolvimento da cultura do milho, p. 31-38. Tecnologia E Produção: Milho Safrinha e Culturas de Inverno. Available on: <http://atividaderural. com.br/artigos/4fb3e56aa8c56.pdf>.

$$
* * * * * * * * * *
$$
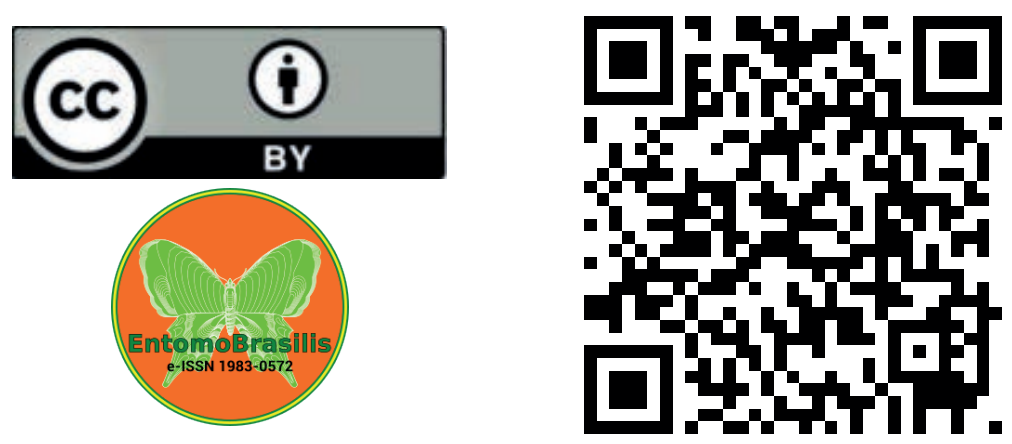